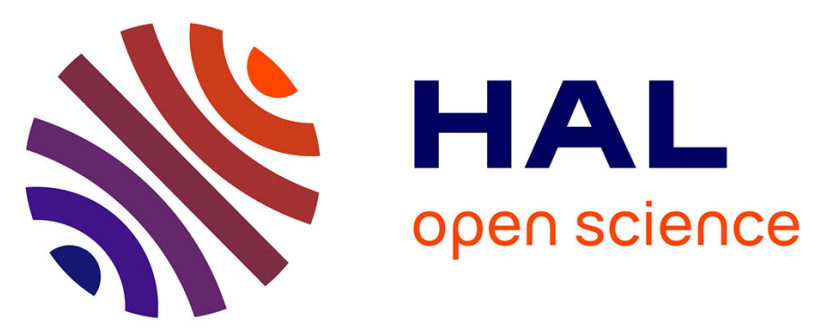

\title{
Influence of Chironomus riparius (Diptera, Chironomidae) and Tubifex tubifex (Annelida, Oligochaeta) on oxygen uptake by sediments. Consequences of uranium contamination
}

S. Lagauzère, Laura Pischedda, Philippe Cuny, Franck Gilbert, Georges Stora, J.M. Bonzom

\section{To cite this version:}

S. Lagauzère, Laura Pischedda, Philippe Cuny, Franck Gilbert, Georges Stora, et al.. Influence of Chironomus riparius (Diptera, Chironomidae) and Tubifex tubifex (Annelida, Oligochaeta) on oxygen uptake by sediments. Consequences of uranium contamination. Environmental Pollution, 2009, 157 (4), pp.1234-1242. 10.1016/j.envpol.2008.12.004 . hal-00390300

\section{HAL Id: hal-00390300 https://hal.science/hal-00390300}

Submitted on 9 Feb 2022

HAL is a multi-disciplinary open access archive for the deposit and dissemination of scientific research documents, whether they are published or not. The documents may come from teaching and research institutions in France or abroad, or from public or private research centers.
L'archive ouverte pluridisciplinaire $\mathbf{H A L}$, est destinée au dépôt et à la diffusion de documents scientifiques de niveau recherche, publiés ou non, émanant des établissements d'enseignement et de recherche français ou étrangers, des laboratoires publics ou privés. 


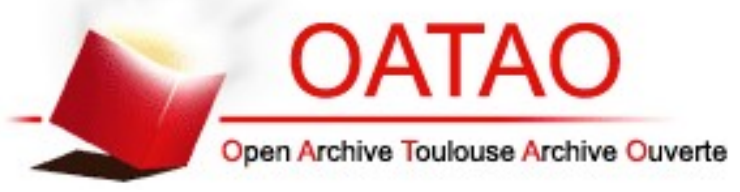

\section{Open Archive Toulouse Archive Ouverte (OATAO)}

OATAO is an open access repository that collects the work of Toulouse researchers and makes it freely available over the web where possible.

This is an author-deposited version published in: http://oatao.univ-toulouse.fr/ Eprints ID: 6085

To link to this article: DOI:10.1016/j.envpol.2008.12.004 http://dx.doi.org/10.1016/j.envpol.2008.12.004

To cite this version : Lagauzère, Sandra and Pischedda, Laura and Cuny, Philippe and Gilbert, Franck and Stora, Georges and Bonzom, Jean-Marc Influence of Chironomus riparius (Diptera, Chironomidae) and Tubifex tubifex (Annelida, Oligochaeta) on oxygen uptake by sediments. Consequences of uranium contamination. (2009) Environmental Pollution, vol. 157 ( ${ }^{\circ}$ 4). pp. 1234-1242. ISSN 0269-7491 


\title{
Influence of Chironomus riparius (Diptera, Chironomidae) and Tubifex tubifex (Annelida, Oligochaeta) on oxygen uptake by sediments. Consequences of uranium contamination
}

\author{
S. Lagauzère ${ }^{\mathrm{a}, *}$, L. Pischedda ${ }^{\mathrm{b}}$, P. Cuny ${ }^{\mathrm{b}}$, F. Gilbert $^{\mathrm{c}}$, G. Stora ${ }^{\mathrm{b}}$, J.-M. Bonzom $^{\mathrm{a}}$ \\ a Laboratoire de Radioécologie et d'Ecotoxicologie, Institut de Radioprotection et de Sûreté Nucléaire (IRSN), DEI/SECRE/LRE, Cadarache 186, BP 3, F-13115 Cedex, \\ Saint Paul Lez Durance, France \\ ${ }^{\mathrm{b}}$ Laboratoire de Microbiologie, Géochimie et Ecologie Marines, UMR 6117 CNRS/COM/Université de la Méditerranée, Campus de Luminy, Case 901, F-13288 Cedex 09, \\ Marseille, France \\ ${ }^{\mathrm{c}}$ EcoLab, Laboratoire d'Ecologie Fonctionnelle, UMR 5245 CNRS/INP/Université Paul Sabatier, 29 Rue Jeanne Marvig, F-31055 Cedex 4, Toulouse, France
}

This study highlights the ecological importance of bioturbation in metal-contaminated sediments.

Keywords:

Bioturbation

Freshwater macroinvertebrates

Diffusive oxygen uptake

Sediments

Heavy metals

\begin{abstract}
A B S T R A C T
The diffusive oxygen uptake (DOU) of sediments inhabited by Chironomus riparius and Tubifex tubifex was investigated using a planar oxygen optode device, and complemented by measurements of bioturbation activity. Additional experiments were performed within contaminated sediments to assess the impact of uranium on these processes. After $72 \mathrm{~h}$, the two invertebrate species significantly increased the DOU of sediments (13-14\%), and no temporal variation occurred afterwards. Within contaminated sediments, it was already $24 \%$ higher before the introduction of the organisms, suggesting that uranium modified the sediment biogeochemistry. Although the two species firstly reacted by avoidance of contaminated sediment, they finally colonized it. Their bioturbation activity was reduced but, for T. tubifex, it remained sufficient to induce a release of uranium to the water column and an increase of the DOU (53\%). These results highlight the necessity of further investigations to take into account the interactions between bioturbation, microbial metabolism and pollutants.
\end{abstract}

\section{Introduction}

The oxygen uptake rate at the sediment-water interface is the main parameter used to estimate the benthic mineralization of organic matter occurring in the early diagenesis of sediments (Thamdrup and Canfield, 2000). It is considered as a relevant indicator of the biogeochemical functioning of sediments. Oxygen consumption by sediments results both from abiotic and biotic processes. Molecular diffusion from the water column and advection forces induce oxygen penetration into sediments of a few millimeters or centimeters (Jorgensen and Revsbech, 1985). The thickness of the oxic layer is negatively correlated to amount and flux of organic matter coming from the overlying water. An increase of organic matter input in surface sediments will lead to the increase of biological oxygen demand and thus to the reduction of the thickness of the oxygenated layer. The sediment-water interface constitutes a dynamic zone with intense oxygen consumption by heterotrophic and lithoautotrophic organisms but also production

\footnotetext{
* Corresponding author. Tel.: +3344219 9426.

E-mail address: lagauzere@gmail.com (S. Lagauzère).
}

by benthic photosynthetic communities. Sediment-dwelling macrofauna, in addition to its own respiration, exerts a strong influence on sediment properties that can enhance oxygen penetration and uptake rate (e.g. Heilskov and Holmer, 2001; Karlson, 2007). Particle mixing and solute transport induced by macrofauna bioturbation lead to a three-dimensional structuring of sediment in a mosaic of microenvironments with different physical, chemical and biological properties (Kristensen, 2000). Bioturbation favors abiotic redox reactions and the growth and the development of some aerobic microbial communities and meiofauna (Aller and Aller, 1986). These organisms could in return influence chemical reactions in zones with variable redox conditions. Oxygen uptake rate (and it) has been used in many studies to assess the impact of macroinvertebrate bioturbation (e.g. resulting from burrowing, food foraging, defecation, respiration activities), particularly in marine ecosystems (e.g. Glud et al., 2003; Mermillod-Blondin et al., 2004; Wenzhöfer and Glud, 2004; Michaud et al., 2005; Zorn et al., 2006), where the benthic metabolism has been shown to increase from 25 to $271 \%$ (Kristensen, 2000).

Comparatively, for freshwater ecosystems, there are few studies dealing with the influence of macroinvertebrate bioturbation on 
oxygen consumption by sediments. Most of the time measurements were associated to studies related to nitrogen cycling, gases or nutrients fluxes at the sediment-water interface as well as in burrow walls. Most of them concerned sediment-dwelling insect larvae (Wang et al., 2001; Stief et al., 2004; Leal et al., 2007), principally Chironomid larvae (Frenzel, 1990; Svensson and Leonardson, 1996; Svensson, 1997; Kajan and Frenzel, 1999; Lewandowski et al., 2007), which irrigate their burrows more or less permanently. Some experiments were also conducted with Tubificid worms (Mc Call and Fisher, 1980; Matisoff, 1995; Pelegri and Blackburn, 1995; Svensson et al., 2001; Mermillod-Blondin et al., 2005; Nogaro et al., 2007). Precise measurements performed in the burrows of freshwater benthic macroinvertebrates and in the corresponding surrounding sediments, particularly through microsensor experiments, clearly demonstrated that these organisms, globally smaller than marine invertebrates, can also enhance oxygen and nutrient fluxes. Nevertheless, it remains difficult to perform microsensor profiles in highly bioturbated sediments and to obtain an integrative response of sediments by averaging local one-dimensional-profiles, and so, to compare efficiently sediments with and without bioturbation. Recent developments in twodimensional $\mathrm{O}_{2}$ sensors - planar optodes - now enable detailed analysis and quantification of the oxygen distribution dynamics into sediments at a high spatial and temporal resolution (Glud et al., 1996). Although there is an increasing use of optode measurements in bioturbation studies in marine ecosystems (e.g. Timmermann et al., 2006; Behrens et al., 2007), only one study involving freshwater macroinvertebrates is currently reported in the literature (Polerecky et al., 2006).

The main objective of the present study is to provide new insights relative to the influence of bioturbation of two freshwater macroinvertebrate species, at relative high densities, on the global oxygen uptake of sediments using a planar optode device through a 12-day laboratory microcosm experiment.

The species Chironomus riparius (Diptera, Chironomidae) and Tubifex tubifex (Annelida, Tubificidae) were chosen as biological models because of their widespread distribution and abundance in freshwater ecosystems and their belonging to two distinct bioturbation functional groups as defined by Gérino et al. (2003).

C. riparius larvae are surface deposit-feeders with a low burrowing activity mainly dependent of oxygen and organic matter availability and presence of predators in the water column (Rasmussen, 1984; Hölker and Stief, 2005). The intermittent ventilation of their tubes induces a slight downward transport of sediment particles and influences solute fluxes at the sedimentwater interface (Stief and De Beer, 2002, 2006; Stief, 2007).

T. tubifex worms are 'conveyer-belt' subsurface deposit-feeders, living head-down oriented and partially submerged in the sediment, with the posterior section of the body free in the overlying water so as to ensure cutaneous respiration. Foraging galleries into the sediment, these worms ingest sediment particles in reduced sediment and excrete them at the surface within fecal pellets (Palmer, 1968). This results in a high and ordered mixing of sediment particles with a dominant upward transport and effects on solute distribution (Mc Call and Fisher, 1980; Matisoff, 1995; Pelegri and Blackburn, 1995; Svensson et al., 2001; Mermillod-Blondin et al., 2005; Nogaro et al., 2007).

To complete our analysis, measurements were additionally performed within uranium-contaminated sediments. Uranium is a natural radioactive heavy metal whose content in the environment has increased due to human activities, particularly in freshwater ecosystems (e.g. Baborowski and Bozau, 2006) where it can accumulate in sediments. Natural uranium concentrations considered as the 'background level' for freshwater sediments range below $10 \mu \mathrm{g} \mathrm{U} \mathrm{g}^{-1}$ dry weight (Kurnaz et al., 2007 and references therein), but concentrations exceeding several hundreds to several thousands of $\mu \mathrm{g} \mathrm{U} \mathrm{g}^{-1}$ dry wt have been registered in rivers and lakes closed to mining sites in Canada, Spain or Australia (Hart et al., 1986; Lozano et al., 2002; Lottermoser et al., 2005). Given that uranium can negatively affect benthic macroinvertebrates (Environnement Canada, 2003; Dias et al., 2008; Lagauzère et al., 2009), and influence microbial community metabolism (for reviews see: Wall and Krumholz, 2006; Wilkins et al., 2006; Renshaw et al., 2007), we have studied here the potential consequences of sediment contamination on oxygen fluxes at the sediment-water interface.

\section{Materials and methods}

2.1. Sediment and water preparation

Sediment and water used in our experiments were sampled from a closed channel of a lake on the Verdon River (Lac d'Esparron, south-eastern France). This sampling site was chosen because of the nature of the sediment (fine mud) and the quality of water (low turbidity, no pollution). Sediments were sieved through a 2$\mathrm{mm}$ mesh to remove coarse fragments (e.g. stones, leaves, and wastes) and macrofauna, and kept frozen at $-20^{\circ} \mathrm{C}$ for a week in order to kill most of organisms that may have been present. After thawing and homogenization (mixing by mechanical stirring), they were kept at $4{ }^{\circ} \mathrm{C}$ until setting up the microcosms. The water was filtered trough a $20-\mu \mathrm{m}$ filter and then stored at $4{ }^{\circ} \mathrm{C}$.

\subsection{Microcosm setting-up}

Two beakers of sediment were prepared: one non-contaminated hereafter referred to as 'control' and a second one that was spiked with a solution of uranyle nitrate $\mathrm{UO}_{2}\left(\mathrm{NO}_{3}\right)_{2} \cdot 6 \mathrm{H}_{2} \mathrm{O}$ (Sigma-Aldrich, France) to obtain end concentration of $600 \mu \mathrm{g} \mathrm{U} \mathrm{g}^{-1}$ of dry sediment. Previous work performed in the same experimental conditions has demonstrated that this concentration was sublethal for the two studied species with an $\mathrm{LC}_{50}$ of $851 \mu \mathrm{g} \mathrm{U} \mathrm{g}^{-1}$ wt for Chironomus riparius and $2320 \mu \mathrm{g}$ $\mathrm{U} \mathrm{g}^{-1}$ wt for Tubifex tubifex, respectively (Lagauzère et al., 2009). The beakers of sediment were hand-shaken for $10 \mathrm{~min}$ each day for 2 weeks to ensure that the contamination was homogeneous.

Five separate microcosms, constituted of transparent aquaria $(10 \times 10 \times 20 \mathrm{~cm}$; length $\times$ width $\times$ height) equipped with oxygen optodes on each face, were settled. In order to restrict the organism distribution to the microcosm side, a PVC cube was inserted inside the microcosm that reduced the sediment thickness to $1 \mathrm{~cm}$ in front of the optodes. Microcosms were then filled with $10 \mathrm{~cm}$ height of sediment and $10 \mathrm{~cm}$ height of water. As each microcosm side was isolated from the others, it was then considered as a replicate (i.e. four replicates/microcosm). Five different experimental conditions were considered: contaminated sediment/with Chironomid larvae [U-Chir], contaminated sediment/with Tubificid worms [U-Tub], control sediment/ with Chironomid larvae [C-Chir], control sediment/with Tubificid worms [C-Tub], and control sediment/without Tubificid worms nor Chironomid larvae [C-no].

All microcosms were placed in a closed dark room with a constant temperature of $21^{\circ} \mathrm{C}$ and received a gentle continuous ambient air pumping through the water column. Losses due to evaporation and sampling were systematically compensated by addition of filtered lake water. Prior to inoculation, microcosms were left to equilibrate for 4 weeks.

\subsection{Organism acclimatization and addition}

The Tubificid worms (Tubifex tubifex) came from a commercial breeding (GREBIL \& Fils, Arry, France) whereas the Chironomid larvae (Chironomus riparius) were already reared in the laboratory. For each species, three aquaria $(50 \times 25 \times 25 \mathrm{~cm}$; length $\times$ width $\times$ height) were previously maintained for several months in the same conditions than those used for the experiments (e.g. $10 \mathrm{~cm}$ of sediment, $10 \mathrm{~cm}$ of water, $21^{\circ} \mathrm{C}$, constant air bubbling). Half of the water column was renewed each month and the organisms were fed by addition of Tetramin ${ }^{\circledR}(20 \mathrm{mg}$ per aquarium) twice a week. Exactly 216 Tubificid worms and 51 Chironomid larvae (third and fourth instars, 5-12 mm body length) were introduced per microcosm allocated for their addition, resulting in initial densities of 60,000 and 14,000 ind $\mathrm{m}^{-2}$, respectively. These are typical densities observed under natural conditions (Palmer, 1968; Rasmussen, 1984). After the introduction of organisms, a series of oxygen measurements and corresponding sediment structure images were made daily during the experimental period (12 days).

\subsection{Oxygen optode measurements}

\subsubsection{Oxygen optode}

The two-dimensional oxygen distribution in sediment and overlying water was measured with semi-transparent planar oxygen optodes. Oxygen measurement was 
based on the dynamic quenching of oxygen on an immobilized fluorophore (Kautsky, 1939). The optical sensor was composed of two thin layers, the transparent polyester support foil (HP transparency, C2936A, $\sim 150 \mu \mathrm{m}$ thick) and the sensing layer where the oxygen-quenchable fluorophore, the platinium (II) meso-tetra (pentafluorophenyl) porphyrin (Frontier Scientific Inc.) was embedded in a polystyrene matrix ( $\sim 20 \mu \mathrm{m}$ ) (Papkovsky et al., 1992; Liebsch et al., 2000). Sensing layer mixture was composed of $3 \mathrm{mg}\left(1 \mathrm{mg} \mathrm{mL}^{-1}\right)$ of Pt-PFPP dissolved in $3 \mathrm{ml}$ of toluene (Rathburn Chemicals Ltd) and $0.65 \mathrm{~g} \mathrm{(5 \% )}$ of polystyrene pellets (Acros Organics) dissolved in $15 \mathrm{ml}$ of toluene. The two solutions were mixed and spread on the polyester support foil $\left(300 \mathrm{~cm}^{2}\right)$. The solvent was let to evaporate slowly until the membrane became completely dry. Optodes were further cut to fit inside the different microcosms (one per face).

\subsubsection{Calibration and measurements}

For the oxygen measurement, each microcosm replicate was placed in front of the optical system which was controlled by the Image Pro Plus - Scope Pro package. The optode was excited by a Xenon lamp light (Perkin-Elmer, 300 Watts) passing through a shutter and a glass filter ( $405 \pm 10 \mathrm{~nm}$, Omega Optical). The fluorescence emitted by the optode passed through another glass filter $(654 \pm 24 \mathrm{~nm})$ and was collected by a Peltier cooled 12 bit monochrome CCD camera (KAI 2000 $1600 \times 1200$ pixels, $7.4 \times 7.4 \mu \mathrm{m})$. The oxygen optodes were calibrated before and after each experiment by a 3-points calibration method. For the two intermediate calibration points ( $90 \%$, air bubbling and $50 \%, \mathrm{~N}_{2}$ bubbling) the oxygen concentration was first measured just behind the optode with an oxygen probe (LDO HQ10, Hach) and immediately followed by the capture of the oxygen image. The $0 \%$ saturation was taken in the deeper non-bioturbated sediments.

Three measurements were taken for each replicate (side of microcosm) before introduction of organisms (time 0 ) and repeated after 0.5, 72, 120, 216 and $288 \mathrm{~h}$. Images of the sediment structure were obtained without the use of filters. Their acquisition was performed in darkness during an exposure time of $30 \mathrm{~s}$ and $1 \mathrm{~s}$ for oxygen and sediment structure, respectively. Interval between the two image acquisitions was $30 \mathrm{~s}$. The digital images were then stored in 12 bit gray scale (0-4095). For each time series, the acquisition and storage of images were automatized with a custom-made script. Final image pixel resolution was $56 \mu \mathrm{m}$.

Pixel intensity on the recorded images was then converted in oxygen concentration by the use of a non-linear relation, slightly modified from Stern-Volmer equation (Klimant et al., 1995), allowing to take into account the oxygen quenching constant and the non-quenchable fraction of the luminescence:

$I=I_{0}\left[\alpha+(1-\alpha) \cdot\left(1 /\left(1+K_{\mathrm{sv}} \cdot C\right)\right)\right]$

where $I_{0}$ is the fluorescence intensity in the absence of oxygen, $K_{\mathrm{sV}}$ is the quenching constant expressing the quenching efficiency, $C$ is the oxygen concentration and $\alpha$ is the non-quenchable fraction of the luminescence including scattered stray light. The constants $\alpha$ and $K_{\text {sv }}$ were determinated from the two intermediate calibration points with oxygen concentration $C_{1}$ and $C_{2}$ corresponding to $I_{1}$ and $I_{2}$ intensities respectively, and integrated in Eq. (1):
$K_{\mathrm{sv}}=\left[I_{0}\left(C_{2}-C_{1}\right)-\left(I_{1} C_{2}-I_{2} C_{1}\right)\right] /\left[\left(I_{1}-I_{2}\right) C_{1} C_{2}\right]$

$\alpha=\left[I\left(1+K_{\mathrm{sv}} \mathrm{C}\right)-I_{0}\right] /\left(I_{0} K_{\mathrm{sv}} C_{1}\right)$

Having estimated the $\alpha, K_{\mathrm{sv}}$ and $I_{0}$, oxygen concentration was obtained by rearranging Eq. (1):

$C=\left(I_{0}-I\right) /\left(K_{\mathrm{sv}}\left(I-I_{0} \cdot \alpha\right)\right)$

The applied oxygen optode were custom-made and were homogenous enough, it was therefore possible to use average constants of $\alpha$ and $K_{\mathrm{sv}}$, rather than performing pixel to pixel calibration as in some earlier planar optode studies (Glud et al., 1996).

Oxygen flux $\left(\mathrm{O}_{2}\right.$ uptake rate) and penetration depth $\left(\mathrm{pdO}_{2}\right)$ into the sediment were measured from the obtained images whereas the length of the sediment-water interface $\left(L_{\mathrm{SWI}}\right)$ was measured on the sediment structure images.

\subsubsection{Diffusive oxygen flux calculation}

Vertical oxygen profiles extracted from images (Fig. 1) make it possible to determine diffusive oxygen flux $J_{(\mathrm{z})}$ which was calculated from Fick's first law of diffusion (Berner, 1980; Jorgensen and Revsbech, 1985; Rasmussen and Jorgensen, 1992):

$J_{(\mathrm{z})}=-\Phi D s \frac{\partial C_{(\mathrm{z})}}{\partial z}$,

where $\Phi$ is the porosity, $D s$ is the oxygen diffusion coefficient in sediments $\left(\mathrm{cm}^{2} \mathrm{~s}^{-1}\right)$ $C$ is the oxygen concentration $\left(\mu \mathrm{mol} \mathrm{m}{ }^{-3}\right), z$ is the depth $(\mathrm{cm})$ and $\partial C_{(z)} / \partial z$ is the oxygen gradient. This approach works on the assumption that molecular diffusion is the main oxygen transport mechanism. Oxygen fluxes were calculated by using the software PROFILE (Berg et al., 1998) which fits an overall profile between the sediment-water interface and within the sediment down to the oxygen $0 \%$ level. To make these measurements, we provide to PROFILE some profiles including few points in the overlying water. Three mean oxygen fluxes were calculated per image, each of them based on the average of six to 11 neighboring vertical oxygen profiles from oxygen images ( $2 \mathrm{~cm}$ total height, centered on the SWI).

\subsection{Bioturbation activity measurement}

The bioturbation activity of Tubifex tubifex worms and Chironomus riparius larvae was assessed using green luminophores which are inert sand particles coated with a fluorescent paint $\left(\varnothing=63 \mu \mathrm{m}, \lambda_{\text {excitation }}=450 \mathrm{~nm}, \lambda_{\text {emission }}=520 \mathrm{~nm}\right.$, Geologishpaleontologisches institute and Museum of Kiel University, Germany). One day before introduction of organisms, $2 \mathrm{~g}$ of luminophores were gently deposited on the top of the sediment of each microcosm.

Destructive sampling took place after 12 days of exposure, i.e. $288 \mathrm{~h}$. The overlying water was removed and the sediment core was carefully sliced in fourteen layers of $0.5-\mathrm{cm}$ thickness from 0 to $4 \mathrm{~cm}$ of depth and $1-\mathrm{cm}$ thickness from 4 to $10 \mathrm{~cm}$ of
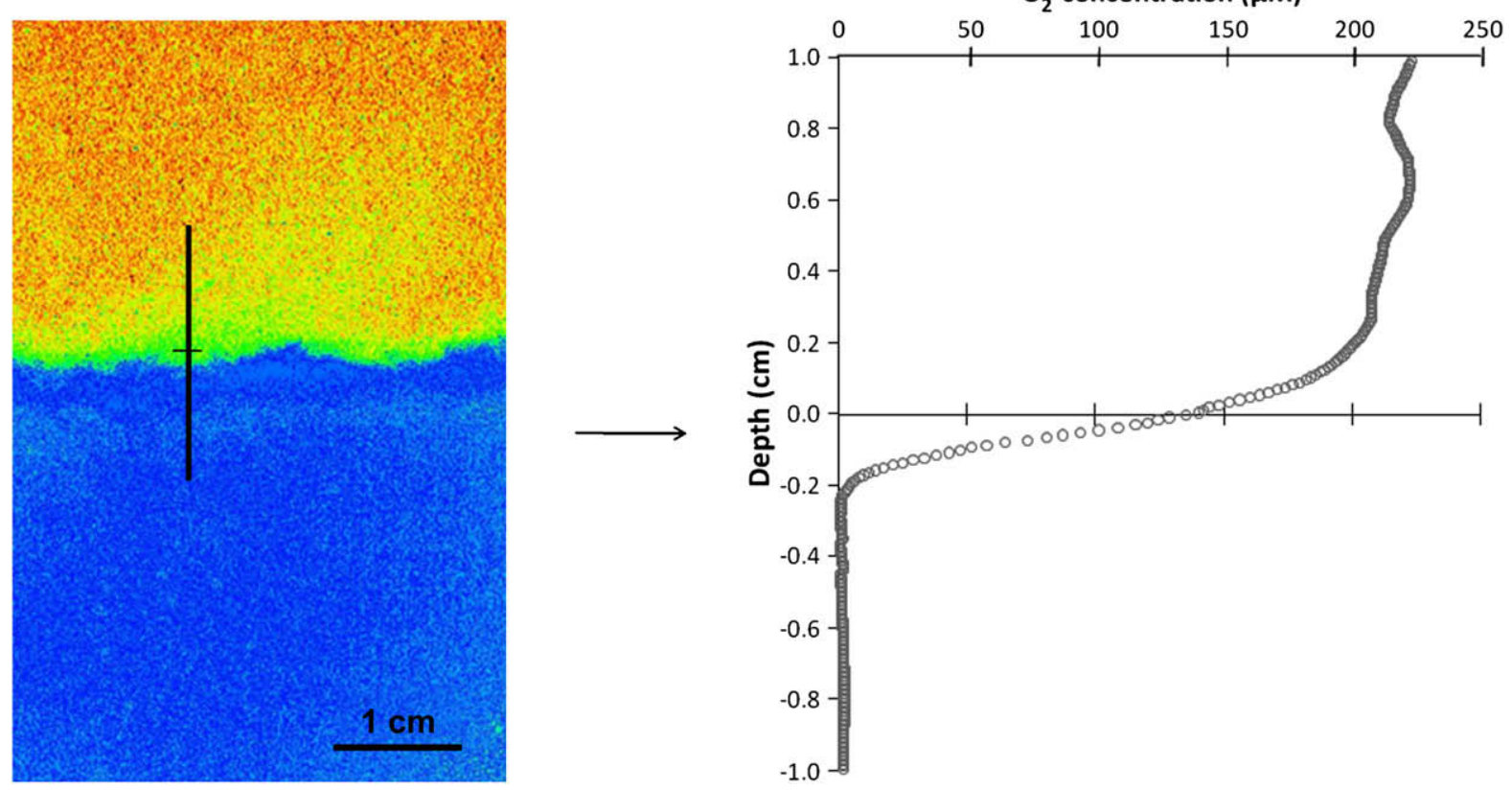

Fig. 1. Example of oxygen vertical profile extracted from a two-dimensional oxygen images (Chironomus riparius in uncontaminated sediment [C-Chir] after 192 h). 
depth. Each layer was hand-homogenized and a sediment subsample was retrieved, weighted and dried $72 \mathrm{~h}$ at room temperature to evaluate the luminophore content. This counting was achieved by a fluorimetric technique after a calibration step with sediment samples of known luminophore concentrations (Lagauzère et al., submitted). From this, the number of luminophores per layer $(n)$ and the total number in the profile $(N)$ were obtained, and hence, the fraction $(n / N)$ of luminophores per layer could be determined. The luminophore concentration was estimated as $C=n$ / $(z \times A \times N)$, where $z(\mathrm{~cm})$ is the thickness of the sampling layer and $A$ the core area. To estimate bioturbation parameters, biodiffusion coefficient $D_{\mathrm{b}}$ and bioadvective rate $V$, the profiles were simulated using the classical biodiffusion-bioadvection model in non-steady state conditions (Officer and Lynch, 1982; Gérino et al., 1994). The maximal depth where luminophores were qualitatively detected by epifluorescence microscopy was also reported as maximal depth of bioturbation (MDB).

\subsection{Physico-chemical measurements}

The temperature, $\mathrm{pH}$, and concentration of dissolved oxygen in the overlying water of the microcosms were measured at days $-2,0$ (introduction of organisms), 4,7 and 12 (end of the experiment). In order to indirectly estimate the release of uranium from the sediment to the overlying water, total uranium concentration was assessed by ICP-AES (Optima $4300 \mathrm{DV}$, Perkin-Elmer, USA) from acidified $\left(2 \% \mathrm{HNO}_{3}\right)$ water samples collected when the aforementioned measurements were taken.

\subsection{Statistical analyses}

All statistical analyses were performed using the STATISTICA ${ }^{\circledR}$ software package (StatSoft, Inc., Tulsa, OK, USA). Before each analysis, the normality (Shapiro-Wilk test) and homogeneity of data variance (Levene test) were tested. It was repeated after transformation of data when these assumptions were not first found. A significance level of $5 \%$ was applied to all analyses.

The physico-chemical parameters, the oxygen uptake rate, the oxygen penetration depth, and the length of the sediment-water interface were analyzed by repeated-measures ANOVAs (RM-ANOVA), both with all the data to test effect of treatment, time, and time * treatment; and with data from 72 to $288 \mathrm{~h}$ to compare treatments after equilibration. These analyses of variance were followed by Newman-Keuls multiple-comparisons tests.

For each macroinvertebrate species, the effects of uranium on bioturbation parameters (bioadvective rate $V$ and biodiffusive rate $D b$ ) were analyzed using oneway ANOVAs, including the control treatment [C-no], followed by Tukey's post hoc comparison tests.

\section{Results}

\subsection{Oxygen uptake rate}

Analysis of oxygen data on times $0,0.5,72,120,216$ and $288 \mathrm{~h}$, revealed significant effects of both time, treatment and time $*$ treatment (RM-ANOVA 'time', 'treatment', 'time $*$ treatment': $F_{4}=6.44, F_{4,13}=4.86, F_{16,52}=3.20$, respectively, $\left.p<0.05\right)$. These differences mainly came from the two first series of data. The analysis of data from 72 to $288 \mathrm{~h}$, showed only a significant effect of treatment (RM-ANOVA 'treatment': $F_{4,15}=10.58, p<0.05$ ) and these data were averaged in order to consider the systems after equilibration (Fig. 2). Three days after introduction of Chironomus riparius and Tubifex tubifex in the microcosms, this parameter has increased of 13 and 14\%, respectively, and remained stable until the end of the experiment. Compared to control treatment [C-no], the oxygen uptake between 72 and $288 \mathrm{~h}$ was 27 and $20 \%$ much higher in C. riparius [C-Chir] and T. tubifex [C-Tub] treatments, respectively.

At the beginning of the experiment, i.e. before introduction of organisms and after 4 weeks of equilibration (time 0 ), the two microcosms corresponding to the uranium-contaminated experimental treatments, [U-Chir] and [U-Tub], had a higher diffusive oxygen uptake rate than uncontaminated microcosms, [C-no], [C-Chir] and [C-Tub] (Newman-Keuls test: $p<0.05$ ). With an oxygen flux at the sediment-water interface of $0.33( \pm 0.08) \mathrm{mmol}$ $\mathrm{O}_{2} \mathrm{~m}^{-2} \mathrm{~h}^{-1}$ in uncontaminated treatments and $0.41( \pm 0.06) \mathrm{mmol}$ $\mathrm{O}_{2} \mathrm{~m}^{-2} \mathrm{~h}^{-1}$ in contaminated treatments, that corresponded to an increase of $24 \%$ in presence of uranium.

Thirty minutes after introduction of organisms in microcosms, oxygen uptake rate was similar for all the treatments, except for [U-Tub] with a lower value (Newman-Keuls test: $p<0.05$ ).

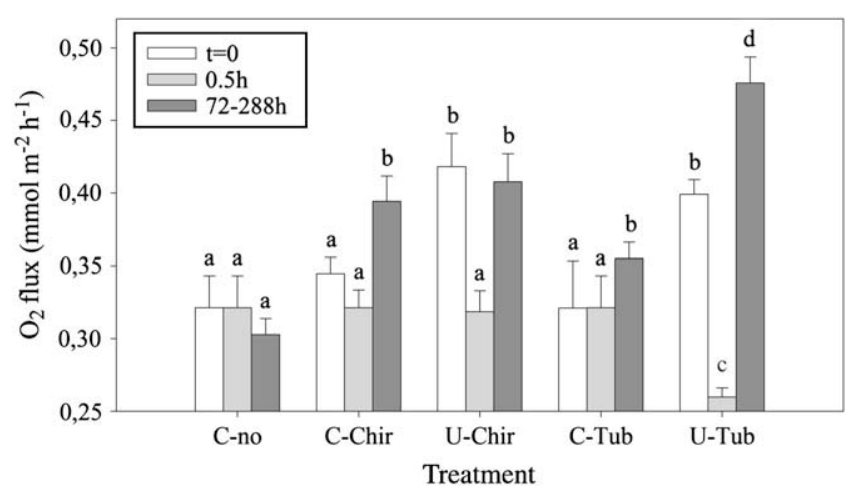

Fig. 2. Oxygen fluxes at the sediment/water interface in the different treatments (C: uncontaminated, U: contaminated, Chir: presence of Chironomus riparius, Tub: presence of Tubifex tubifex, no: no organism) before the introduction of organisms (white bars), after $0.5 \mathrm{~h}$ (gray bars), and after $72 \mathrm{~h}$ to the end (black bars). Means $\pm \mathrm{SD}$ $(N=4)$. Different letters indicate significant differences.

Compared to initial conditions, the oxygen uptake decreased significantly in uranium-contaminated microcosms (NewmanKeuls test: $p<0.05$ ).

During the rest of the experiment, oxygen uptake rate was constant in each treatment (data not shown, RM-ANOVA 'time': $F_{4,15}=1.16, p>0.05$ ). It was significantly higher in all inhabited microcosms than in control microcosm, particularly in the [U-Tub] treatment which was significantly different from all the others (RM-ANOVA 'treatment': $F_{4,15}=10.58, p<0.05$; Newman-Keuls test: $p<0.05)$. Compared to initial conditions, this rate increased during the experiment, except in the [U-Chir] treatment (RMANOVA 'time $*$ treatment': $F_{16,52}=3.20, p<0.05$; Newman-Keuls test: $p<0.05$ ).

\subsection{Oxygen penetration depth $\left(\mathrm{pdO}_{2}\right)$}

As for oxygen uptake rate, RM-ANOVA of all the data concerning $\mathrm{pdO}_{2}$ depth, showed significant effects of time, treatment and time * treatment; while only the treatment had a significant effect with data from 72 to $288 \mathrm{~h}$ (Fig. 3). However, given that any significant difference exist between initial conditions and after $30 \mathrm{~min}$ for each microcosm (RM-ANOVA 'time $*$ treatment': $\left.F_{16,52}=1.33, p>0.05\right)$, only the averaged data from 72 to $288 \mathrm{~h}$

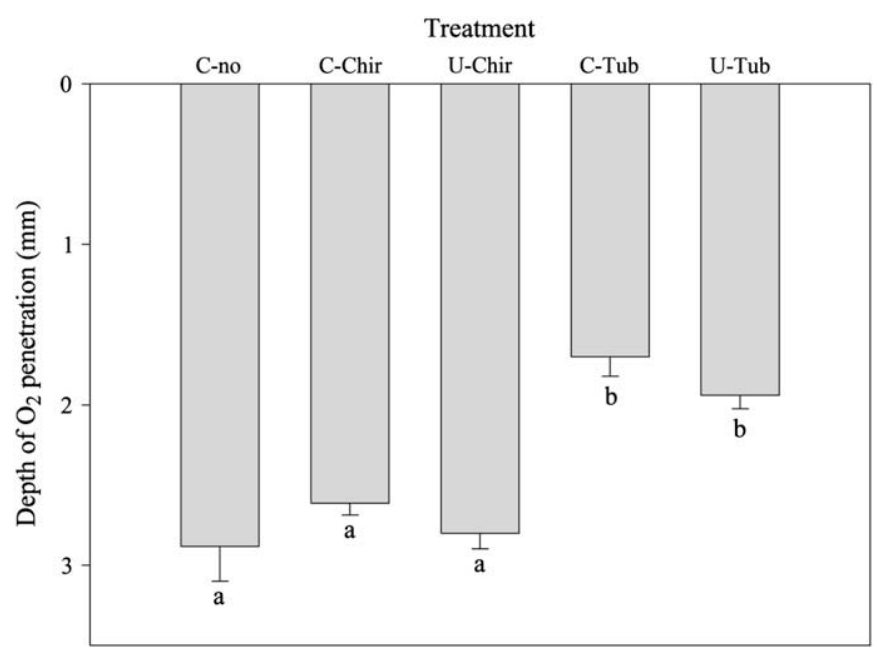

Fig. 3. Depth of oxygen penetration $\mathrm{pdO}_{2}$ into the sediments of the different treatments (C: uncontaminated, U: contaminated, Chir: presence of Chironomus riparius, Tub: presence of Tubifex tubifex, no: no organism). Means $\pm \operatorname{SD}(N=4)$. Different letters indicate significant differences. 
were represented in Fig. 2. Compared to non-inhabited control treatment, the $\mathrm{pdO}_{2}$ was similar in C. riparius treatments, while it was reduced in T. tubifex treatments, independently of the uranium contamination (RM-ANOVA 'treatment': $F_{4,15}=16.932, p<0.05$; Newman-Keuls test: $p<0.05$ ).

\subsection{Length of the sediment-water interface ( $\left.\mathrm{L}_{S W I}\right)$}

For the same reasons than for oxygen penetration, only the averaged $L_{S W I}$ measurements from 72 to $288 \mathrm{~h}$ are represented on Fig. 4. These data showed a significant effect of treatment (RMANOVA 'treatment': $F_{4,15}=10.65, p<0.05$ ). In all inhabited treatments, the $L_{S W I}$ was higher than in the non-inhabited control treatment, and there was a significant difference between [C-Chir] and [C-Tub] treatments (Newman-Keuls test: $p<0.05$ ).

\subsection{Bioturbation activity}

Bioadvective rate $V$ and biodiffusive rate $D b$ estimates from fitting the luminophore profiles after 12 days showed significant effect of uranium on both Chironomus riparius and Tubifex tubifex bioturbation activities (Fig. 5).

C. riparius led to a low sediment particle reworking as illustrated by the slight downward transport of luminophores within the sediment $(<3.5 \mathrm{~cm}$ of depth). This particle burial was lower within uranium-contaminated sediment $(<2.5 \mathrm{~cm}$ of depth). Comparison of [C-no], [C-Chir] and [U-Chir] treatments, showed that the bioturbation of $C$. riparius was mainly limited to biodiffusion processes (quantified by the $D b$ ), and that this parameter was reduced in presence of uranium (ANOVA: $F_{2,6}=273.5, p<0.05$; Tukey test: $p<0.05)$, while any significant difference was detected for bioadvective rate $V$ (ANOVA: $F_{2,6}=0.98, p>0.05$ ).

On the other hand, T. tubifex led to a strong burial of luminophores as attested by the presence of these tracers at the bottom of the uncontaminated microcosm $(10 \mathrm{~cm})$. In uranium-contaminated sediment, no luminophore was detected below $6 \mathrm{~cm}$. Compared to control treatment [C-no], both bioadvection and biodiffusion rates were enhanced in T. tubifex treatments, [C-Tub] and [U-Tub] (ANOVA: $F_{2,6}=396.97$ and $F_{2,6}=13.8$, respectively, $p<0.05$; Tukey test: $p<0.05$ ), but only the bioadvective rate was affected by uranium (Tukey test: $p<0.05$ ).

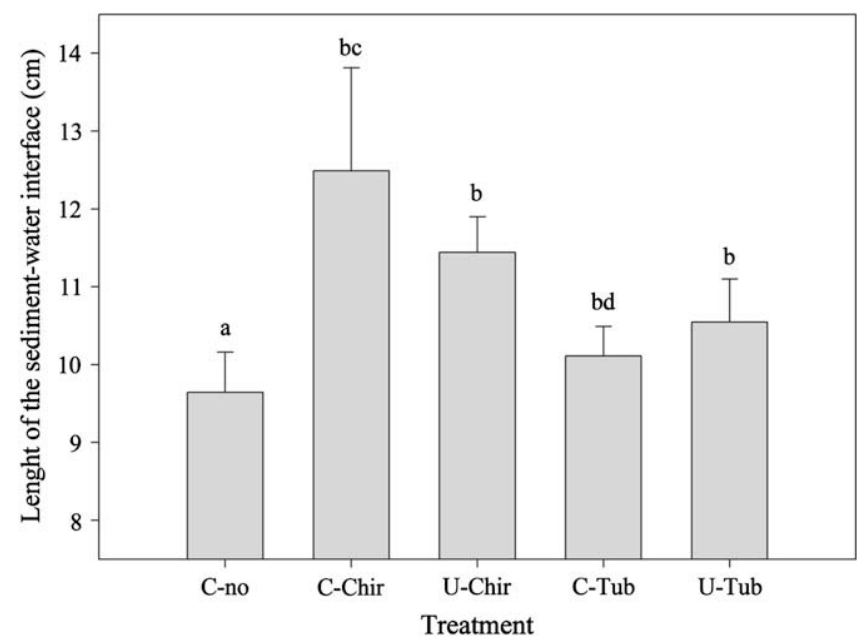

Fig. 4. Length of the sediment/water interface $\mathrm{L}_{S W I}$ of the different treatments (C: uncontaminated, U: contaminated, Chir: presence of Chironomus riparius, Tub: presence of Tubifex tubifex, no: no organism). Means \pm SD $(N=4)$. Different letters indicate significant differences.
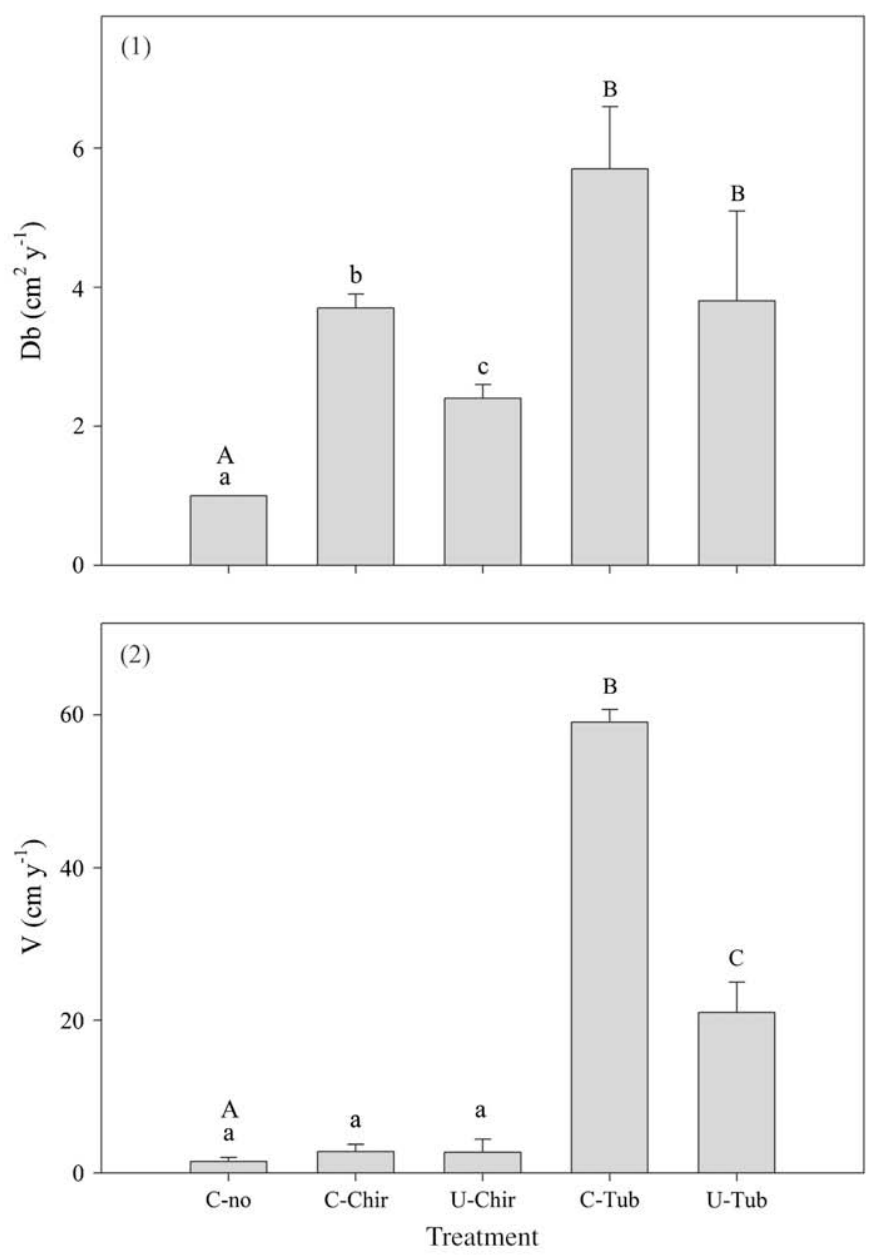

(3)

$\begin{array}{llllll}\mathrm{MDB}(\mathrm{cm}) & 1.5 & 3.5 & 2.5 & 10.0 & 6.0\end{array}$

Fig. 5. Biodiffusion rate $D b(1)$, bioadvection rate $V(2)$, and maximal depth of bioturbation $M D B(3)$ in the different treatments (C: uncontaminated, U: contaminated, Chir: presence of Chironomus riparius, Tub: presence of Tubifex tubifex, no: no organism). Means $\pm \mathrm{SD}(N=4)$. Different letters indicate significant differences (small letters, in C. riparius experiments; capital letters, in T. tubifex experiments).

\subsection{Physico-chemical measurements}

The data set from all of the microcosms showed that the temperature was maintained at $21.1( \pm 0.1)^{\circ} \mathrm{C}$, the dissolved oxygen concentration at $7.7( \pm 0.3) \mathrm{mg} \mathrm{L}^{-1}$ and $\mathrm{pH}$ at $8( \pm 0.2)$ throughout the experiment, without any significant difference between treatments (RM-ANOVA: $p>0.05)$. The total uranium concentration in the water column of microcosms gradually increased over time in both [U-Chir] and [U-Tub] treatments, with a factor of 2.7 and 4.6, respectively (Fig. 6).

\section{Discussion}

\subsection{Effects of bioturbation}

As previously demonstrated both in marine and freshwater ecosystems, the present results confirmed that benthic macroinvertebrates enhance the diffusive oxygen uptake (DOU) of sediments. For instance, the same trend has already been observed for 


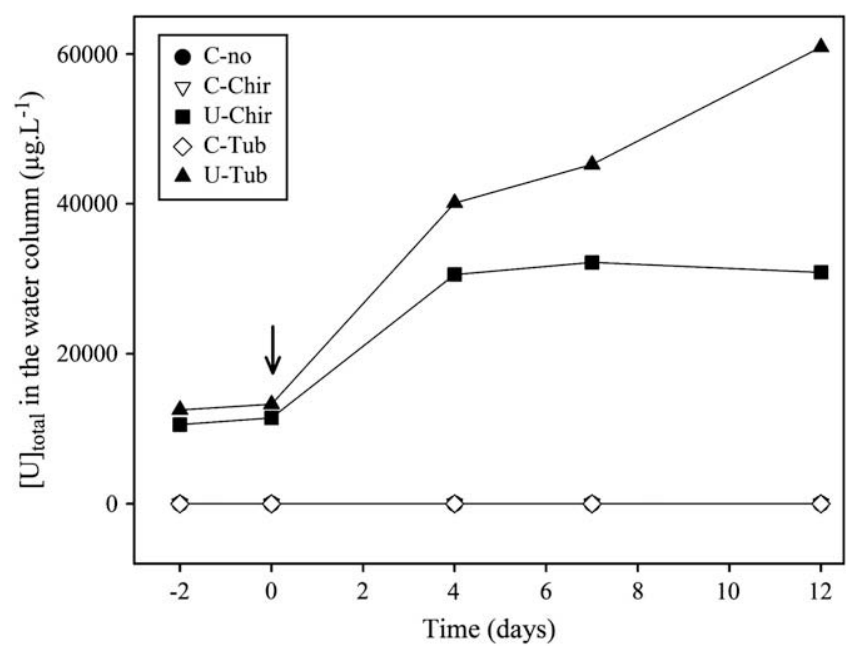

Fig. 6. Evolution of the uranium concentration in the water column of the different microcosms during 12 days (C: uncontaminated, U: contaminated, Chir: presence of Chironomus riparius, Tub: presence of Tubifex tubifex, no: no organism).

Chironomus riparius by Stief and De Beer (2002) and for Tubifex tubifex by Pelegri and Blackburn (1995), by using microsensor measurements. Yet the only experiment using oxygen optodes in freshwater sediments only focuses on local oxygen fluxes in the burrow wall of Chironomus plumosus (Polerecky et al., 2006). The behavior of organisms was the same in our case than in the latter cited experiment, i.e. a rapid burial of organisms into the sediment after their introduction in microcosms. However, these authors measured significantly higher oxygen uptake rates in the sediment surrounding the burrows during 16 min after the introduction of organisms in the sediments; whereas no changes in the DOU was observable $30 \mathrm{~min}$ after the introduction in our study (Fig. 2). Although local changes probably occur very rapidly during the settling of macroinvertebrates into the sediments, changes of the DOU at the benthic interface seem to become visible later.

As the DOU measurements probably included the respiration of animals only at a minor level, the oxygen uptake rate enhancement in microcosms inhabited by C. riparius and T. tubifex can be related to the physical, chemical and biological modifications induced by their bioturbation activities (Fig. 5). Among physical disturbances, in bioturbated sediments, a longer sediment-water interface (Fig. 4) has been shown to favor the oxygen exchanges by increasing the diffusion surface (Pischedda et al., 2008). Advective transport can also be increased due to higher porosity of the uppermost layers of sediments. However, the measured oxygen penetration into the sediment was not higher in C. riparius treatment and was lower in $T$. tubifex treatment, comparatively to control treatment (Fig. 3). Although penetration of oxygen into the sediment due to bioturbation is effective as shown by microsensor measurements in the wall of burrows reported in previous studies (Wang et al., 2001; Polerecky et al., 2006), this result suggests that intense oxygen consumption occurred in subsurface sediments by stimulation of the microbial respiration. Through microcosm experiments, Van de Bund et al. (1994) demonstrated that the microbial production increased by a factor 4.4 and 1.4 in sediments inhabited by $C$. riparius and $T$. tubifex, respectively, despite of reduction of the bacterial abundance.

The consequences of $C$. riparius larvae bioturbation on the sediment biogeochemistry have already been well documented (Rasmussen, 1984; Van de Bund et al., 1994; Stief and De Beer, 2002; De Haas et al., 2005; Hölker and Stief, 2005; Stief, 2007). Larvae can exhibit two distinct behavioral modalities: (i) displacements at the top of the sediment; and/or (ii) digging and irrigating of burrows. Their relative importance is mainly determined upon density of organisms, oxygenation of the overlying water, granulometry and organic content of sediments. In our experiment, both these two behaviors were observed, with no apparent dominance of one of them. At first sight, larvae roamed at the sediment surface where they could feed by grazing leading to the reduction of microbial biomasses. They could also act as deposit-feeders, resulting in the exposition of sediment-associated organic matter to variable oxic and redox conditions through alternative burial/rising and ingestion/egestion of particles. Stief (2007) demonstrated that this mechanism stimulates microbial hydrolytic exoenzyme production and thus the decomposition of organic matter. Furthermore, larvae randomly built burrows into the sediment and irrigate them through intermittent pumping of the overlying water. These burrows clearly enhance the exchange area at the sediment-water interface and as a consequence the fluxes of solutes and gases (Svensson, 1997; Kajan and Frenzel, 1999; Lewandowski et al., 2007). With supply of fresh organic matter linked to mucus and feces production, as well as availability of nutrients, these burrows provide privileged habitats for microbial communities in subsurface sediments (Stief and De Beer, 2002). Therefore, aerobic nitrification can be stimulated by concomitant ventilation and ammonium excretion in the burrows, and denitrification can be facilitated by higher nitrate penetration into periodically anoxic sediment (Svensson and Leonardson, 1996; Svensson, 1997; Stief and De Beer, 2002).

Comparatively, the influence of Tubificid worms on oxygen dynamics has received less attention, principally because they live in non-irrigated galleries. However, their behavior exert a strong influence on sediment reworking and thus on organic matter processing, all the more so their abundance can reach very high values in natural sediments, up to several millions ind $\mathrm{m}^{-2}$ (Palmer, 1968). Their conveyer-belt feeding activity leads to the transport of reduced materials from the bottom sediment to the surface and to the formation of a top layer mainly composed of mucus-bounded fecal pellets. Both abiotic and biotic oxidation reactions are then stimulated. For instance, Mc Call and Fisher (1980) demonstrated that, for a density of 100,000 ind $\mathrm{m}^{-2}$, oxygen uptake rate of sediments was doubled in presence of worms, with $50-70 \%$ relative to the oxidation of removed iron sulfates $(\mathrm{Fe}-\mathrm{S})$ from the bottom sediments, $10-30 \%$ relative to the stimulation of microbial activity, and only $20 \%$ relative to the own respiration of worms. The high porosity of the pelletized top layer, coupling with the higher exchange surface of the sediment-water interface due to the dense network of galleries dug into sediments; enhance diffusion and advection, and then the fluxes of solutes (Matisoff, 1995; Mermillod-Blondin et al., 2005; Nogaro et al., 2007). Therefore, aerobic respiration and denitrification can be stimulated by these worms (e.g. Svensson et al., 2001), proportionally to their density into the sediments (Mc Call and Fisher, 1980; Pelegri and Blackburn, 1995). On the other hand, Pelegri and Blackburn (1995) demonstrated that nitrification was stimulated at low densities $\left(<20,000\right.$ ind $\left.\mathrm{m}^{-2}\right)$ whereas it was inhibited at high densities $(20,000-70,000$ ind $\mathrm{m}^{-2}$ ). These authors suggested that at high densities, the oxygen penetration into the sediments is reduced by the transport of reduced materials and the intense aerobic microbial activity in the feces layer. These anoxic conditions stimulate denitrification and limit nitrification to a very fine layer under the surface of sediments. The lower oxygen penetration measured in T. tubifex treatments (Fig. 3) fits well with this assumption.

Finally, despite their different ways of life, both C. riparius larvae and T. tubifex worms enhanced the oxygen utilization in subsurface sediments, with a quantitatively similar resultant oxygen flux at the sediment-water interface (Fig. 2). However, the density of T. tubifex 
in microcosms was more than four times higher than the density of C. riparius. Given that oxygen uptake rate of sediments is correlated with the density of organisms (Pelegri and Blackburn, 1995; Svensson and Leonardson, 1996), this result suggests that the bioturbation of Chironomid larvae has a more pronounced effect on oxygen distribution than the bioturbation of Tubificid worms. This probably reflects the higher oxygen demand of Chironomid larvae compared to Tubificid worms, and above all the higher impact of bioirrigation on oxygen distribution compared to bioconveying. Svensson et al. (2001) suggested the same interpretation for the influence of the bioturbation on denitrification. Be that as it may, the applied densities of organisms fall well within the range of abundances that are realistic for natural sediments.

\subsection{Consequences of sediment uranium contamination}

At initial conditions (time 0 ), the oxygen uptake rate of sediments was $24 \%$ higher in uranium-contaminated microcosms compared to uncontaminated microcosms (Fig. 2). Given that sediments were contaminated before introduction of Chironomus riparius and Tubifex tubifex, this result suggests that uranium directly influenced the benthic biogeochemistry. Two assumptions can be proposed: the oxidation of uranium into the sediment consumed oxygen and/or uranium modified the microbial community by directly or indirectly stimulating aerobic organisms. The first hypothesis can be consistent with the uranium concentration measured at initial conditions in the water column. Indeed, before the setting-up of microcosms, the sediments were spiked with uranium in a close beaker. Given the low oxygen availability, uranium contained in the sediments might be under its reduced form, at the redox state (+IV), which is not soluble (Markich, 2002). During the 4 weeks of equilibration of the microcosms, the exposure to a constantly aerated water column, probably favored the oxidation of uranium in $\mathrm{U}(+\mathrm{VI})$ in surface sediments, and thus its higher solubility (Markich, 2002). The relative high uranium concentration observed in the water column before the introduction of organisms may reflect the release of uranium from the sediments during this step of the experiment. The second hypothesis related to the stimulation of microbial respiration by uranium is more difficult to assess. Most of available literature dealing with the interactions between sedimentary micro-organisms and uranium focuses on immobilization of uranium through the bioreduction of $\mathrm{U}(+\mathrm{VI})$ in $\mathrm{U}(+\mathrm{IV})$ in the context of bioremediation of contaminated sites (Wall and Krumholz, 2006; Wilkins et al., 2006; Renshaw et al., 2007). The toxicity of uranium to micro-organisms has been so far poorly investigated, but it seems to be much lower than toxicity of other heavy metals (Nies, 1999). A case of resistance was also reported on an aerobic bacterium which can incorporate uranium in the form of intra-cytoplasmic polyphosphate-associated granules by a detoxification process (Suzuki and Banfield, 2004). Furthermore, uranium may be positive factor for some micro-organisms as it can be a potential substrate for anaerobic respiration (Lovley et al., 1991). Most of iron-reducing micro-organisms able to conserve energy by coupling $\mathrm{H}_{2}$ and organic matter oxidation with the reduction of ferrous ions can also reduce uranium. Some sulphatereducers bacteria can also enzymatically reduce ferrous ions and uranium without keeping energy or grow up with either ferrous ions or uranium as sole electron acceptor (Wilkins et al., 2006). In natural uranium-contaminated environments, it was demonstrated that anaerobic prokaryotes were easily cultivable on nuclear wastes, and that nitrate-reducers represent a dominant community (Akob et al., 2007). However, neither negative nor positive effects on aerobic microbial communities non-previously exposed to uranium were reported. Therefore, the present results demonstrated that more investigations are required to assess the interactions between uranium and micro-organisms in a different context of bioremediation. Finally, although the preparation of sediments avoided the persistence of meiofauna in the microcosms, it can not be excluded that some organisms were maintained after all. Even there is no data in the literature concerning uranium toxicity to meiofauna living in sediments; several authors reported negative effects for other heavy metals (e.g. Gyedu-Ababio and Baird, 2006; Heininger et al., 2007). Uranium could have affected some meiofauna, decreasing the grazing pressure on micro-organisms, and leading to the supply of labile organic matter which could have stimulated the microbial activity.

Thirty minutes after introduction of $C$. riparius larvae and $T$. tubifex worms into the contaminated microcosms, the oxygen uptake dramatically decreased in both cases. Such a result was not observed in uncontaminated microcosms indicating that the sudden exposure to uranium modified the behavior of organisms with a significant impact on oxygen uptake of sediments. In the contaminated sediments, it was noticed that organisms regrouped themselves and that their burial into the sediments was visibly reduced. It is probable that such a concentration of organisms at the sediment-water interface has limited the diffusion of oxygen into the sediments. Avoidance of sediment polluted with metals was previously described for Chironomid larvae (Wentsel et al., 1977) and Tubificid worms (Meller et al., 1998; West and Ankley, 1998). Moreover, the latter are known to congregate together in a form of a tightly packed mass when exposed to environmental perturbations (Palmer, 1968). This phenomenon was effectively observed at the time of the introduction of the worms in the microcosms which may explain why these organisms induced a strongest limitation on oxygen diffusion. However, after $24 \mathrm{~h}$, the organisms have colonized the sediments, and the subsequent measurements of oxygen uptake rates have shown similar values as initial conditions (data not shown). Compared to uncontaminated treatments, the burial of organisms into the sediments was delayed but not inhibited, even if the maximal depth of burial during the rest of the experiment was lower (Fig. 5).

As in uncontaminated microcosms, oxygen measurements performed between 72 and $288 \mathrm{~h}$ did not show any significant temporal variation. Compared with initial conditions, T. tubifex increased the oxygen uptake of sediments by $18 \%$, whereas C. riparius larvae did not induce significant difference. In the case of C. riparius, the negative effects of uranium have probably limited the effect of bioturbation on oxygen dynamics into the sediments. On the other hand, in the case of T. tubifex, such a conclusion can not be drawn as the oxygen uptake rate was surprisingly higher despite of the significant reduction of bioturbation intensity induced by uranium (Fig. 5). Compared to control treatment [C-no], the association of uranium contamination with the presence of $T$. tubifex lead to the increase of $53 \%$ of the oxygen consumption of sediments. Without additional investigations to understand the interactions between uranium, bioturbation and microbial communities into the sediment, we can only speculate that $T$. tubifex stimulated some micro-organisms already favored by uranium contamination, such as nitrate-reducers, metal-reducers or sulphate-reducers. However, these organisms have generally an anaerobic metabolism which can not totally explain the higher consumption of oxygen, even if, for instance, some sulphate-reducers can use $\mathrm{O}_{2}$ as terminal electron acceptor. Likewise, reduced compounds (e.g. $\mathrm{NH}_{4}^{+}$, $\mathrm{Fe}^{2+}, \mathrm{S}_{2}^{-}$) produced by anaerobic metabolism can diffuse and be re-oxidized at the sediment surface. On the other hand, aerobic micro-organisms can be stimulated by the supply of fresh organic matter induced by the effect of uranium on T. tubifex. Indeed, it was demonstrated that, in the same experimental conditions and for the same level of contamination, the worms secreted more mucus to protect themselves and reacted by a caudal autotomy process 
permitting their detoxification (Lagauzère et al., 2009). Additionally to the death of some individuals ( $20 \%)$, these mechanisms may therefore induce a significant supply of organic matter all the more so the initial density of worms into the sediments was high. Finally, despite their more surficial distribution into uranium-contaminated sediment $(<6 \mathrm{~cm}), T$. tubifex continued to remove reduced materials from the bottom sediments, as attested by the significant bioadvection of particles (Fig. 5). This can be related to the increase of uranium concentration in the water column during the 12 days of exposure, which was probably due to the removal of uranium from the sediment through egestion of fecal pellets and its subsequent reoxidation.

\section{Conclusion}

This work confirmed the ecological importance of Chironomid larvae and Tubificid worms within freshwater benthic ecosystems. Despite of their different ways of life, the bioturbation of these two different taxonomic groups stimulated the microbial metabolism into the sediments. Although a lower influence of bioturbation was expected within uranium-contaminated sediment, it was demonstrated that this can be straight contradicted in the case of Tubificid worms, since their presence strongly increased the oxygen uptake of the sediments. This result raises fundamental questions concerning the interactions existing between bioturbation, microorganisms and metallic pollutants into freshwater sediments.

\section{Acknowledgments}

We would like to thank Virginie Camillieri for technical assistance with ICP-AES, and the two anonymous reviewers for their very helpful comments. This work was supported by the EnvirHom research program funded by the Institute of Radioprotection and Nuclear Safety (IRSN, France).

\section{References}

Akob, D.M., Mills, H.J., Kostka, J.E., 2007. Metabolically active microbial communities in uranium-contaminated subsurface sediments. FEMS Microbiology Ecology 59, 95-107.

Aller, J.Y., Aller, R.C., 1986. Evidence for localized enhancement of biological activity associated with tube and burrow structures in deep-sea sediments at the HEBBLE site, western North Atlantic. Deep-Sea Research 33, 755-790.

Baborowski, M., Bozau, E., 2006. Impact of former mining activities on the uranium distribution in the River Saale (Germany). Applied Geochemistry 21, 1073-1082.

Behrens, J.W., Stahl, H.J., Steffensen, J.F., Glud, R.N., 2007. Oxygen dynamics around buried lesser sandeels Ammodytes tobianus (Linnaeus 1785): mode of ventilation and oxygen requirements. Journal of Experimental Biology 210, 1006-1014.

Berg, P., Risgaard-Petersen, N., Rysgaard, S., 1998. Interpretation of measured concentration profiles in sediment pore water. Limnology and Oceanography 43, 1500-1510.

Berner, R.A., 1980. Early Diagenesis: A Theoretical Approach. Princeton University Press, USA.

De Haas, E.M., Kraak, M.H.S., Koelmans, A.A., Admiraal, W., 2005. The impact of sediment reworking by opportunistic chironomids on specialised mayflies. Freshwater Biology 50, 770-780.

Dias, V., Vasseur, C., Bonzom, J.-M., 2008. Exposure of Chironomus riparius larvae to uranium: effects on survival, development time, growth, and mouthpart deformities. Chemosphere 71, 574-581.

Environnement Canada, 2003. Liste des substances d'intérêt prioritaire - Rapport d'évaluation - Rejets de radionucléides des installations nucléaires (effets sur les espèces autre que l'être humain), Gouvernement du Canada.

Frenzel, P., 1990. Influence of Chironomid larvae on sediment oxygen microprofiles. Archiv für Hydrobiologie AHYBA4 119, 427-437.

Gérino, M., Stora, G., Durbec, J.-P., 1994. Quantitative estimation of biodiffusive and bioadvective sediment mixing: in situ experimental approach. Oceanologica Acta 17, 547-554.

Gérino, M., Vervier, P., Stora, G., Gilbert, F., Poggiale, J.-C., François-Carcaillet, F., Mermillod-Blondin, F., Desrosiers, G., 2003. Macro-invertebrate functional groups in freshwater and marine sediments: a common mechanistic classification. Vie et Milieu 53, 221-232.
Glud, R.N., Ramsing, N.B., Gundersen, J.K., Klimant, I., 1996. Planar optrodes: a new tool for fine scale measurements of two-dimensional $\mathrm{O}_{2}$ distribution in benthic communities. Marine Ecology Progress Series 140, 217-226.

Glud, R.N., Gundersen, J.K., Røy, H., Jørgensen, B.B., 2003. Seasonal dynamics of benthic $\mathrm{O}_{2}$ uptake in a semienclosed bay: importance of diffusion and faunal activity. Limnology and Oceanography 48, 1265-1276.

Gyedu-Ababio, T.K., Baird, D., 2006. Response of meiofauna and nematode communities to increased levels of contaminants in a laboratory microcosm experiment. Ecotoxicology and Environmental Safety 63, 443-450.

Hart, D.R., Mc Kee, P.M., Burt, A.J., Goffin, M.J., 1986. Benthic community and sediment quality assessment of Port Hope Harbour, Lake Ontario. Journal of Great Lakes Research 12, 206-220.

Heilskov, A.C., Holmer, M., 2001. Effects of benthic fauna on organic matter mineralization in fish-farm sediments: importance of size and abundance. ICES Journal of Marine Science 58, 427-434

Heininger, P., Höss, S., Claus, E., Pelzer, J., Traunspurger, W., 2007. Nematode communities in contaminated river sediments. Environmental Pollution 146, 64-76.

Hölker, F., Stief, P., 2005. Adaptive behaviour of chironomid larvae (Chironomus riparius) in response to chemical stimuli from predators and resource density. Behavioral Ecology and Sociobiology 58, 256-263.

Jorgensen, B.B., Revsbech, N.P., 1985. Diffusive boundary layers and the oxygen uptake of sediments and detritus. Limnology and Oceanography 30, 111-122.

Kajan, R., Frenzel, P., 1999. The effect of chironomid larvae on production, oxidation and fluxes of methane in a flooded rice soil. FEMS Microbiology Ecology 28, $121-129$.

Karlson, K., 2007. Diurnal bioturbating activities of Monoporeia affinis: effects on benthic oxygen and nutrient fluxes. Marine Ecology Progress Series 331, 195-205.

Kautsky, H., 1939. Quenching of luminescence by oxygen. Transactions of the Faraday Society 35, 216-219.

Klimant, I., Meyer, V., Kuhl, M., 1995. Fiber-optic oxygen microsensors, a new tool in aquatic biology. Limnology and Oceanography 40, 1159-1165.

Kristensen, E., 2000. Organic matter diagenesis at the oxic/anoxic interface in coastal marine sediments, with emphasis on the role of burrowing animals. Hydrobiologia 426, 1-24.

Kurnaz, A., Küçükömeroglu, B., Keser, R., Okumusoglu, N.T., Korkmaz, F., Karahan, G. Cevik, U., 2007. Determination of radioactivity levels and hazards of soil and sediment samples in Firtina Valley (Rize, Turkey). Applied Radiation and Isotopes 65, 1281-1289.

Lagauzère, S., Terrail, R., Bonzom, J-M., 2009. Ecotoxicity of uranium on Tubifex tubifex (Annelida, Clitellata, Tubificidae) exposed to contaminated sediment. Ecotoxicology and Environmental Safety 72, 527-537.

Leal, J.J.F., Dos Santos Furtado, A.L., De Assis Esteves, F., Bozelli, R.L., FigueiredoBarros, M.P., 2007. The role of Campsurus notatus (Ephemeroptera: Polymitarcytidae) bioturbation and sediment quality on potential gas fluxes in a tropical lake. Hydrobiologia 586, 143-154.

Lewandowski, J., Laskov, C., Hupfer, M., 2007. The relationship between Chironomus plumosus burrows and the spatial distribution of pore-water phosphate, iron and ammonium in lake sediments. Freshwater Biology 52, 331-343.

Liebsch, G., Klimant, I., Frank, B., Holst, G., Wolfbeis, O.S., 2000. Luminescence lifetime imaging of oxygen, $\mathrm{pH}$, and carbon dioxide distribution using optical sensors. Applied Spectroscopy 54, 548-559.

Lottermoser, B., Ashley, P., Costelloe, M., 2005. Contaminant dispersion at the rehabilitated Mary Kathleen uranium mine, Australia. Environmental Geology 48, 748-761.

Lovley, D.R., Phillips, E.J.P., Gorby, Y.A., Landa, E.R., 1991. Microbial reduction of uranium. Nature 350, 413-416.

Lozano, J.C., Blanco Rodríguez, P., Vera Tomé, F., 2002. Distribution of long-lived radionuclides of the ${ }^{238} \mathrm{U}$ series in the sediments of a small river in a uranium mineralized region of Spain. Journal of Environmental Radioactivity 63,153-171.

Markich, S.J., 2002. Uranium speciation and bioavailability in aquatic systems: an overview. The Scientific World Journal [electronic resource] 2, 707-729.

Matisoff, G., 1995. Effects of bioturbation on solute and particle transport in sediments. In: Allen, H.E. (Ed.), Metal Contaminated Aquatic Sediments. Ann Arbor Press, Chelsea, MI, pp. 203-271.

Mc Call, P.L., Fisher, J.B., 1980. Effects of tubificid oligochaetes on physical and chemical properties of Lake Erie sediments. In: Brinkhurt, R.O., Cook, D.G. (Eds.), Aquatic Oligochaete Biology. Plenum Press, New York, pp. 253-317.

Meller, M., Egeler, P. Römbke, J., Schallnass, H., Nagel, R. Streit, B. 1998. Short-term toxicity of lindane, hexachlorobenzene, and copper sulfate to tubificid sludgeworms (oligochaeta) in artificial media. Ecotoxicology and Environmental Safety 39, 10-20.

Mermillod-Blondin, F., Rosenberg, R., Norling, K., François-Carcaillet, F. Mauclaire, L., 2004. Influence of bioturbation by three benthic infaunal species on microbial communities and biogeochemical processes in marine sediment. Aquatic Microbial Ecology 36, 271-284.

Mermillod-Blondin, F., Nogaro, G., Datry, T., Malard, F., Gibert, J., 2005. Do tubificid worms influence the fate of organic matter and pollutants in stormwater sediments? Environmental Pollution 134, 57-69.

Michaud, E., Desrosiers, G., Mermillod-Blondin, F., Sundby, B., Stora, G., 2005. The functional group approach to bioturbation: I. The effects of biodiffusers and gallery-diffusers of the Macoma balthica community on sediment oxygen uptake. Journal of Experimental Marine Biology and Ecology 326, 77-88.

Nies, D.H., 1999. Microbial heavy-metal resistance. Applied Microbiology and Biotechnology 51, 730-750. 
Nogaro, G., Mermillod-Blondin, F., Montuelle, B., Boisson, J.C., Lafont, M., Volat, B., Gibert, J., 2007. Do tubificid worms influence organic matter processing and fate of pollutants in stormwater sediments deposited at the surface of infiltration systems? Chemosphere 70, 315-328.

Officer, C.B., Lynch, D.R., 1982. Interpretation procedures for the determination of sediment parameters from time-dependent flux inputs. Earth and Planetary Science Letters 61, 55-62.

Palmer, M.F., 1968. Aspects of the respiratory physiology of Tubifex tubifex in relation to its ecology, 154. Journal of Zoology, London. 463-473.

Papkovsky, D.B., Olah, J., Troyanovsky, I.V., Sadovsky, N.A., Rumyantseva, V.D. Mironov, A.F., Yaropolov, A.I., Savitsky, A.P., 1992. Phosphorescent polymer films for optical oxygen sensors. Biosensors and Bioelectronics 7, 199-206.

Pelegri, S.P., Blackburn, T.H., 1995. Effects of Tubifex tubifex (Oligochaeta: Tubificidae) on $\mathrm{N}$-mineralization in freshwater sediments, measured with ${ }^{15} \mathrm{~N}$ isotopes. Aquatic Microbial Ecology 9, 289-294.

Pischedda, L., Poggiale, J.-C., Cuny, P., Gilbert, F., 2008. Imaging oxygen distribution in marine sediments. The importance of bioturbation and sediment heterogeneity. Acta Biotheoretica, 1-13.

Polerecky, L., Volkenborn, N., Stief, P., 2006. High temporal resolution oxygen imaging in bioirrigated sediments. Environmental Science and Technology 40 5763-5769.

Rasmussen, J.B., 1984. The life-history, distribution, and production of Chironomus riparius and Glyptotendipes paripes in a prairie pond. Hydrobiologia 119, 65-72.

Rasmussen, H., Jorgensen, B.B., 1992. Microelectrode studies of seasonal oxygen uptake in a coastal sediment: role of molecular diffusion. Marine Ecology Progress Series 81, 289-303.

Renshaw, J.C., Lloyd, J.R., Livens, F.R., 2007. Microbial interactions with actinides and long-lived fission products. Comptes Rendus Chimie 10, 1067-1077.

Stief, P., 2007. Enhanced exoenzyme activities in sediments in the presence of deposit-feeding Chironomus riparius larvae. Freshwater Biology 52, 1807-1819.

Stief, P. De Beer, D. 2002. Bioturbation effects of Chironomus riparius on the benthic $\mathrm{N}$-cycle as measured using microsensors and microbiological assays. Aquatic Microbial Ecology, 175-185.

Stief, P., De Beer, D., 2006. Probing the microenvironment of freshwater sediment macrofauna: Implications of deposit-feeding and bioirrigation for nitrogen cycling. Limnology and Oceanography 51, 2538-2548.

Stief, P., Altmann, D., De Beer, D., Bieg, R., Kureck, A., 2004. Microbial activities in the burrow environment of the potamal mayfly Ephoron virgo. Freshwater Biology 49, 1152-1163.
Suzuki, Y., Banfield, J.F., 2004. Resistance to, and accumulation of, uranium by bacteria from a uranium-contaminated site. Geomicrobiology Journal 21, 113-121.

Svensson, J.M., 1997. Influence of Chironomus plumosus larvae on ammonium flux and denitrification (measured by the acetylene blockage- and the isotope pairing-technique) in eutrophic lake sediment. Hydrobiologia 346, 157-168.

Svensson, J.M., Leonardson, L., 1996. Effects of bioturbation by tube-dwelling chironomid larvae on oxygen uptake and denitrification in eutrophic lake sediments. Freshwater Biology 35, 289-300.

Svensson, J.M., Enrich-Prast, A., Leonardson, L., 2001. Nitrification and denitrification in a eutrophic lake sediment bioturbated by oligochaetes. Aquatic Microbial Ecology 23, 177-186.

Thamdrup, B., Canfield, D.E., 2000. Benthic respiration in aquatic sediments. In: Sala, O.E., Mooney, H.A., Jackson, R.B., Howarth, R.W. (Eds.), Methods in Ecosystems Science. Springer, New York, pp. 86-103.

Timmermann, K., Banta, G.T., Glud, R.N., 2006. Linking Arenicola marina irrigation behavior to oxygen transport and dynamics in sandy sediments. Journal of Marine Research 64, 915-938.

Van de Bund, W.J., Goedkoop, W., Johnson, R.K., 1994. Effects of deposit-feeder activity on bacterial production and abundance in profundal lake sediment ournal of the North American Benthological Society 13, 532-539.

Wall, J.D., Krumholz, L.R., 2006. Uranium reduction, Annual Review of Microbiology, 149-166.

Wang, F., Tessier, A., Hare, L., 2001. Oxygen measurements in the burrows of freshwater insects. Freshwater Biology 46, 317-327.

Wentsel, R., Mc Intosh, A., Mc Cafferty, W.P., Atchison, G., Anderson, V., 1977. Avoidance response of Midge Larvae (Chironomus Tentans) to sediments containing heavy metals. Hydrobiologia 55, 171-175.

Wenzhöfer, F., Glud, R.N., 2004. Small-scale spatial and temporal variability in coastal benthic $\mathrm{O}_{2}$ dynamics: effects of fauna activity. Limnology and Oceanography 49, 1471-1481.

West, C.W., Ankley, G.T., 1998. A laboratory assay to assess avoidance of contaminated sediments by the freshwater Oligochaete Lumbriculus variegatus. Archives of Environmental Contamination and Toxicology 35, 20-24.

Wilkins, M.J., Livens, F.R., Vaughan, D.J., Lloyd, J.R., 2006. The impact of Fe(III)reducing bacteria on uranium mobility. Biogeochemistry 78, 125-150.

Zorn, M.E., Lalonde, S.V., Gingras, M.K., Pemberton, S.G., Konhauser, K.O., 2006 Microscale oxygen distribution in various invertebrate burrow walls. Geobiology 4, 137-145. 